\title{
Türkiye'de Sektörel Enerji Kullanımındaki Değişimlerin İtici Güçleri: Ayrıştırma Analizi
}

\begin{abstract}
Kumru TÜRKÖZ ${ }^{1}$
$\ddot{O} z$

Bu çalışmada, 1970-2018 döneminde ekonomik ve demografik yapısında önemli değişiklikler meydana gelen Türkiye'de sektörel enerji kullanımındaki değişikliklerin itici güçlerini incelemek amaçlanmaktadır. Buradan hareketle çalışmada, bu değişikliklerin tarım, sanayi, konut ve hizmetler ile ulaştırma gibi birincil sektörlerdeki enerji kullanımı üzerindeki etkileri Logaritmik Ortalama Divisia İndeksi (Logarithmic Mean Divisia Index [LMDI])'nin toplamsal tipte ayrıştırma analizi versiyonu kullanılarak araştırılmaktadır. Analiz sonuçları; incelenen dönemde ortalama olarak sektörel enerji kullanımının her bir sektörde çıktı etkisi ile arttığını, tarım sektörü hariç diğer sektörlerde ise yoğunluk etkisi ile azaldığını göstermektedir. Diğer bir ifade ile çıktı etkisi üretim artısı kanalıyla sektörel enerji kullanımı üzerinde yoğun bir etkiye sahipken, yoğunluk etkisi sektörlerdeki enerji yoğunluğunun kısmen düşme eğilimi içinde olması nedeniyle sektörel enerji kullanımı üzerinde düşürücü bir etki yaratmaktadır. Yapısal etki ise tarım ve sanayi sektörlerinde enerji kullanımını düşürücü, konut ve hizmetler ile ulaştırma sektörlerinde ise enerji kullanımını arttırıcı etki yaratmaktadır. Sektörlerin enerji kullanımlarında meydana gelen bu etkilerin farklılaşmasının, incelenen dönemde meydana gelen yapısal dönüşüme bağlı olarak ülkenin izlediği ekonomi politikalarının farklılaşmasından kaynaklandığı düşünülmektedir.
\end{abstract}

Anabtar Kelimeler: Sektörel Enerji Kullanımı, Toplamsal Tipte Ayrıştırma Analizi, Türkiye.

\section{The Driving Forces of Changes in Energy Sector Consumption in Turkey:}

\section{Decomposition Analysis}

\begin{abstract}
This paper aims to investigate the driving forces of changes in energy sector consumption in Turkey for the 19702018 period when significant changes occurred in the economic and demographic structure of the country. For this purpose, the study investigates the effects of these changes on energy consumption in primary sectors such as agriculture, industry, housing and services, and transportation using the additive version of the Logarithmic Mean Divisia Index (LMDI) decomposition analysis. The results of analysis show that on average, energy consumption increased with the influence of the volume of output in each sector, whereas it is decreased with the influence of intensity in sectors except agriculture. In other words, while the output effect has an intense influence on the energy consumption sector through the increase in production, the intensity effect has a decreasing influence on the energy consumption sector due to the decreasing tendency of the energy density in sectors. The structural effect, on the other hand, creates an effect that decreases energy consumption in agriculture and industry sectors, and increases energy consumption in housing and services and transportation sectors. It is thought that the differentiation of these effects occurring in the energy use of the sectors is due to the differentiation of the economic policies followed by the country depending on the structural transformation that occurred in the period examined.
\end{abstract}

Key Words: Energy Consumption Sector, Additive Version of the Decomposition Analysis, Turkey.

Atıf İçin / Please Cite As:

Türköz, K. (2021). Türkiye'de sektörel enerji kullanımındaki değişimlerin itici güçleri: Ayrıştırma analizi. Manas Sosyal Arasttrmalar Dergisi, 10(2), 1038-1052.

Geliş Tarihi / Received Date: 04.01.2021

Kabul Tarihi / Accepted Date: 05.02.2021

\footnotetext{
${ }^{1}$ Arş. Gör. Dr. - Balıkesir Üniversitesi İktisadi ve İdari Bilimler Fakültesi, kumru.turkoz@balikesir.edu.tr 


\section{Giriş}

Son yıllarda, enerji sektörü yalnızca uluslararası politikaları ve bölgesel eğilimleri belirlemede değil, aynı zamanda küresel etkileri olan ekonomik kararların alınmasında ve uygulanmasında da kilit bir rol oynamaktadır. Tarım, ulaştırma, sanayi ve hizmetler başta olmak üzere tüm iş kolları ve sektörleri doğrudan etkileyen, çok katmanlı ve çok boyutlu bir yapı sergileyen enerji sektörü, hem Türkiye'de hem de dünyada yakından izlenmekte, incelenmekte ve tartışılmaktadır (Industrial Development Bank of Turkey [TSKB], 2019, s. 5). Ancak enerjinin üretimdeki rolünü anlamadan enerjinin ekonomik büyümedeki rolünü anlamak mümkün değildir. Üretime yönelik bazı girdiler yeniden üretilemezken, diğerleri ekonomik üretim sistemi dâhilinde belirli bir maliyetle yeniden üretilebilir. Sermaye, emek ve hatta daha uzun vadede doğal kaynaklar, üretimin yeniden üretilebilir faktörleridir; enerji ise, üretimin yeniden üretilemez bir faktörüdür. $\mathrm{Bu}$ nedenle, ekolojik iktisatçılar, enerjinin ekonomik üretim ve büyüme süreçlerindeki rolüne ve mevcudiyetine çok yoğun bir vurgu yapmaktadır (Stern ve Cleveland, 2004, s. 3-4). Diğer taraftan son 50 yıldır gelişmekte olan ülkelerdeki ekonomik gelişme sürecinin artan enerji talebi ile çok güçlü bir etkileşim içerisinde olması da bu sebepten kaynaklanmaktadır (Jobert ve Karanfil, 2007, s. 5447).

Enerjinin ekonominin performansı için hayati olduğu uzun zamandır tartısılmaktadır. Enerji, sadece maliyetini fiyata katarak üretilen ürünlerin değerine katkıda bulunan sıradan bir ara ürün olarak değil, aynı zamanda üretim doğrultusunda üretim faktörleri listesine dâhil edilmesi gereken değer yaratan bir faktör olarak değerlendirilmelidir (Pokrovski, 2003, s. 770). Oysa geleneksel (ana akım) büyüme teorileri, ekonomik büyümeyi sağlamada enerjinin veya diğer doğal kaynakların rolüne ya çok az önem vermekte ya da hiç dikkate almayarak enerjiye dişsal bir rol biçmektedir (Toman ve Jemelkova, 2003, s. 8). Bu nedenle bu ekonomik modeller enerjiyi ekonomik büyümeyi kıstlayabilecek veya mümkün kılabilecek bir faktör olarak üretim sürecine dâhil etmemektedir (Stern, 2010, s. 3). Bunun yanı sıra bazı ekolojik ekonomistler, büyümenin artan enerji kullanımının veya artan enerji kullanımına izin veren yeniliklerin bir sonucu olduğunu savunarak, teknolojik değişimin verimlilik artışındaki rolünü önemsememektedirler. Bu nedenle, bu görüşe göre, artan enerji kullanımı ekonomik büyümenin ana veya tek nedenidir ve değer, sermaye ve emeğin yönlendirdiği enerji eyleminden kaynaklanmaktadır (Clevelend, Costanza, Hall ve Kaufman, 1984, s. 891; Stern, 2020, s. 35-36).

Enerjinin büyüme içerisindeki rolüne ilişkin farklı yaklaşımlar bulunsa da enerji mevcudiyeti, ekonominin işleyişi için bir ön şarttır ve çoğu malın üretim maliyetlerini önemli ölçüde etkilemektedir. Enerjinin tartışmasız teorik ve pratik önemi göz önüne alındığında, bu faktörün ekonomik büyüme ve kalkınma için önemli bir temel oluşturduğu söylenebilir (Jakovac, 2018, s. 280). Bu sebeple özellikle son otuz yll içinde ekonomik büyüme ve enerji kullanımı arasındaki karşılıklı bağımllık ve nedensellik ilişkisini inceleyen geniş bir literatür oluşmaya başlamıştır. Literatürdeki enerji kullanımı-büyüme ilişkisi bu çalışmada Türkiye açısından sektörel dönüşümler dikkate alınarak incelenmektedir. Çalışmada sektörlerin enerji kullanımlarının özellikle hangi etkiler nedeniyle artış gösterdiği ayrıştırılarak analiz edilmektedir. Böylelikle analiz bulgularının Türkiye'deki enerji politikalarının belirlenmesi sürecine katkıda bulunabilmesi hedeflenmektedir. Bu kapsamda ekonomik büyüme ile enerji kullanımı arasındaki karşılıklı bağımlılık ilişskisinin teorik çerçevesine kısaca değinilen giriş bölümünün ardından, ikinci bölümde Türkiye'de 1970'lerdan bu yana ekonomik gelişmeler, toplam enerji kullanımının gelişimi ve enerjinin sektörel düzeyde tüketim trendleri analiz edilmektedir. Üçüncü bölümde; konu ile ilgili ampirik literatüre yer verildikten sonra, dördüncü bölümde ekonometrik yöntem ve veri seti tanıtılmaktadır. Beşinci bölümde ampirik bulgulara yer verilmekte ve son olarak altıncı bölümde politika sonuçları tartışılmaktadır.

\section{Türkiye'deki Sektörel Gelişmeler ve Enerji Kullanımı: Makroekonomik Arka Plan}

Türkiye stratejik bir coğrafi konuma, güçlü ve girişimci bir iş sektörüne, büyük bir iç pazara ve büyüyen bir genç nüfusa sahiptir. Ancak son dönemlerde Türkiye ekonomisi, çoğunlukla ucuz dış finansman sayesinde hızlı büyürken bazı yapısal dengesizlikler ortaya çıkmış ve bu durum ekonominin kırılganlı̆̆ını artırmıştır (European Commission, 2019, s. 11). Bu olumsuz gelişmelere rağmen kişi başına düssen Türkiye Gayri Safi Yurtiçi Hasıla (GSYİH)'si, daha gelişmiş Ekonomik Kalkınma ve İşbirliği Örgütü (Organisation for Economic Cooperation and Development [OECD]) ekonomilerine yakınsamaya devam etmiş ve GSYİH büyümesi 2010-2017'ye göre ortalama \%7 oranında gerçekleşmiştir. Ülkede işgücü verimliliği, özellikle tarımda, düşük üretkenliğe sahip kayıt dışı faaliyetin yaygınlığına rağmen, diğer birçok OECD ekonomisini aşmaktadır. Ancak bunların yanında talebin büyük ölçüde iç tüketim tarafindan yönlendirilmesi, iç tasarrufun toplam yatırımın gerisinde kalması ve dış borcun yükselişte olması gibi 
yapısal dengesizlikler büyümenin sürdürülebilirliğini tehlikeye atmaktadır (OECD, 2018, s. 13-16). Ekonomik teoride büyümenin sürdürülebilir kılınması için ise (i) toplam üretimde sanayi ve hizmet sektörü çıktısının paylarının artırılması, (ii) toplam istihdam içerisinde yüksek verimlilikli istihdamın artırılması ve (iii) toplam üretim içerisinde yüksek katma değerli ürünlerin payının artırılması gerektiği kabul edilmektedir (Rada ve Von Arnim, 2012, s. 264). Bu koşulları ekonomi politikaları içerisine entegre etmeye çalşan Türkiye'de özellikle gelişme ve kalkınma ile birlikte üretimin ağırlı̆ıının tarımdan sanayi ve hizmetler sektörüne doğru belirgin bir şekilde kaydığı gözlemlenmektedir. Şekil 1'de yer verildiği gibi Türkiye İstatistik Kurumu (TÜIK) (2020) ${ }^{2}$ verilerine göre; 1970 yllında tarımın GSYİH içerisindeki payı yaklaşık $\% 31$, sanayinin pay1 $\% 19$, konut ve hizmetler ${ }^{3}$ sektörünün pay1 $\% 43$, ulaştırma sektörünün pay1 $\% 7$ dolaylarında iken, 2018 yılı itibarıly bu oran tarımda yaklaşık \%6'ya gerilerken, sanayide \%20'ye, konut ve hizmetler sektöründe neredeyse \%63'e ve ulaştırma sektöründe \%12'ye yükselmiştir. 2000'li yıllarda tarımın milli gelir içerisindeki payının \%13’lere düşmesiyle birlikte hizmetler sektörü milli gelire en büyük katk1 sağlayan sektörlerden biri haline gelmiş ve onu sanayi sektörü izlemiştir. Bu dönemden itibaren hizmetler ve sanayi sektörü Türkiye'nin milli gelirine neredeyse $\% 87$ oranında katkıda bulunmaktadır.

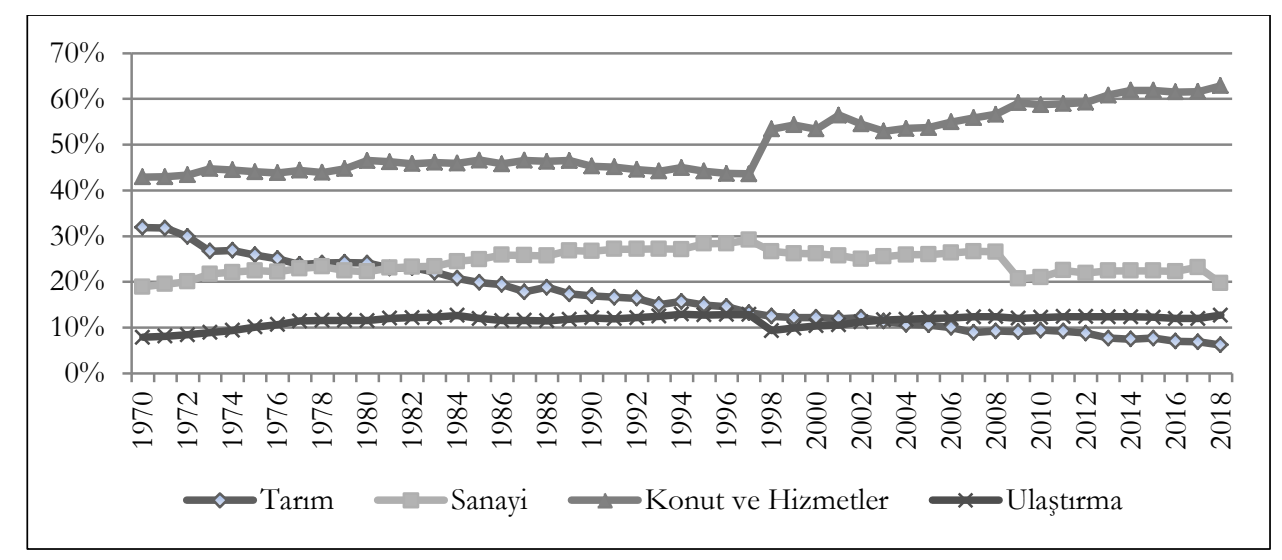

Şekil 1. Sektörlerin GSYIH İserisindeki Paylar (\%) (1970-2018) (TÜIK, 2020)

Ülkede bu yapısal dönüşümler yaşanırken 1960-1980 dönemi kapalı ve planlı bir ekonomi, 1980-2000 ihracata dayalı büyüme stratejisine sahip açık bir ekonomi ve 2000 yllından itibaren yapisal reformların hızlandırılması ile sürdürülebilir bir büyüme anlayışı benimsenmiştir (Jobert ve Karanfil, 2007, s. 5448). 1980'lerde dünya ekonomisinin yeniden yapılanmasının bir parçası olarak birçok ülke benzer bir dönüşüm geçirmiş olsa da Türkiye, yapısal dönüşümü etkin bir şekilde uygulayan öncü ülkelerden biri olmuştur. Ancak ülkenin ekonomisi, demografisi ve enerjisi arasındaki mevcut ilişki, dönüşüm süreçlerinin henüz tamamlanmadığını göstermektedir (Öniş, 1991, s. 27; Ediger ve Huvaz, 2006, s. 733). Türkiye'nin kişi başına enerji ve elektrik kullanımı OECD ortalamasının altında seyretmektedir. Ancak halen gelişmekte olan bir ülke olarak, Türkiye'nin OECD ülkelerine kıyasla kişi başına enerji kullanımı artışının gelecekte çok daha yüksek olması beklenmektedir (Turkey Energy Outlook, 2020, s. 24). Enerji ve Tabi Kaynaklar Bakanlığ (ETKB) (2020) Enerji Denge Tabloları (1970-2018) incelendiğinde; ülkenin 1970 yllinda toplam enerji arzında ithalatın payı \%32 iken, 2018 yllına gelindiğinde bu oranın neredeyse \%80’lere ulaştığını söylemek mümkündür. Enerji kullanımının yakın gelecekte daha hızlı bir artış göstereceği senaryoları dikkate alındığında, yabancı kaynaklardan elde edilen enerji kaynaklarına bağımllık, ülkede sürdürülebilirliğin ve kalkınma hedeflerinin önünde önemli bir engel olarak görünmektedir.

Türkiye'nin ekonomik üretimine paralel olarak enerji kullanımının tarihsel gelişimine bakıldığında; ulaştırma ve tarım sektörü dışında diğer sektörlerde döngüsel bir modelde rastlanabileceği gibi sık dalgalanmalar olduğu görülmektedir. 1970 yllından 2018 yllına kadar tarım sektörünün milli gelir içerisindeki payı belirgin bir şekilde azalmasına rağmen enerji kullanımlarının istikrarlı bir seyir izlediği ve sektörün enerji ihtiyacının genel olarak her dönemde nihai enerji talebinin \%5'inden daha azına tekabül

\footnotetext{
2 Sektörel GSYİH değerleri alınırken TÜİK tarafından yıllar itibarıyla açıklanan sektörlerin GSYİH içerisindeki payları alınmıştır. Ancak konut ve ulaştırma sektörünü hizmetler sektörü içerisinden ayrıştırmak için sektörel GSYİH değerleri zincirlenmiş hacim endeksi olarak Bin TL cinsine dönüştürülmüş ve sektörlerin oransal payları yıllık olarak yeniden hesaplanmıştır.

${ }^{3}$ Konut ve ulaştırma sektörleri hizmetler ana sektörünün içerisinde yer almasına rağmen çalışmada sektörel enerji kullanımının daha derinlemesine ayrıştırılması amaçlandığından konut ve ulaştırma ayrı olarak ele alınmıştır. Konut sektörüne ait GSYİH verilerinin hizmetler sektörü ile birlikte verilmesinin temel nedeni ise, Enerji ve Tabi Kaynaklar Bakanllğı (ETKB) (2020)'de 19702018 dönemi boyunca sektörel enerji kullanımı verilerine konut ve hizmetler sektörü olarak bir arada yer verilmesinden kaynaklanmaktadır. Böylelikle sektörlerin büyüme oranları ile enerji kullanımlarını karşılaştırmalı olarak incelemek hedeflenmiştir.
} 
ettiği Şekil 2'de açıkça görülmektedir. İncelenen dönemde milli gelir içerisindeki en yüksek payı konut ve hizmetler sektörü almasına karşılık enerji kullanımındaki en yüksek artışın sanayi sektöründe olduğu dikkat çekmektedir. Ulaştırma sektöründeki enerji kullanımının ise sektörün milli gelir içerisindeki payı ile paralel olarak hareket ettiğini, 2010 yllına kadar her dönemde sektörün enerji kullanımının nihai enerji kullanımının ortalama \%20'sine denk geldiğini ancak 2010 yılından sonra enerji talebinin belirgin bir şekilde artış eğilimine girdiğini söylemek mümkündür.

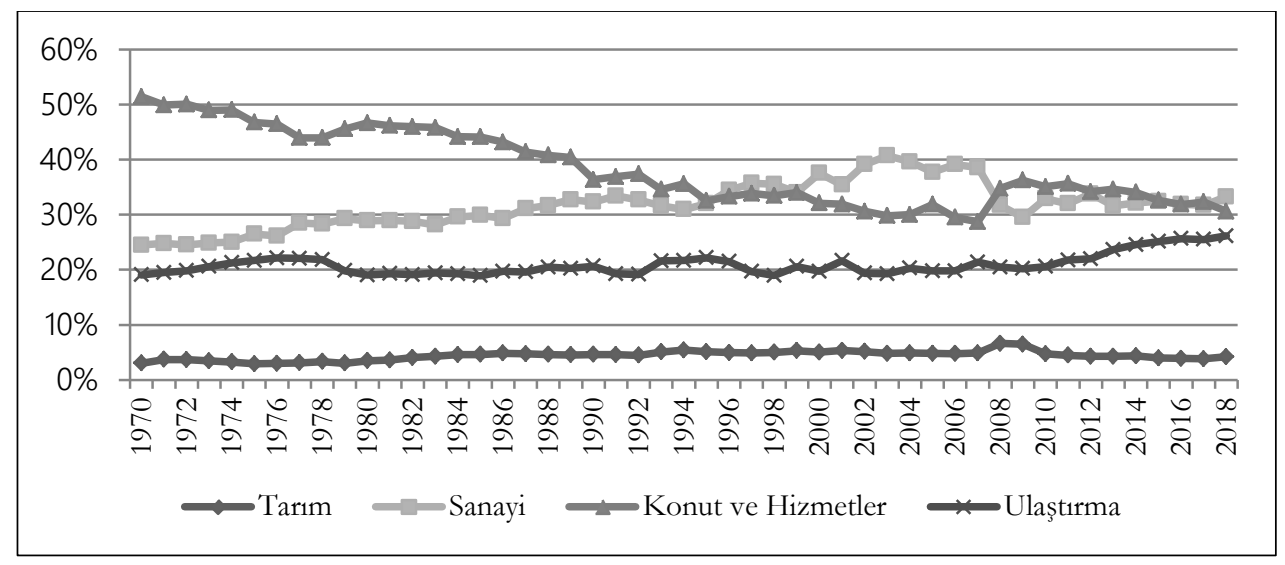

Şekil 2. Sektörel Enerji Kullanmmmm Toplam Enerji Kullanmı İcerisindeki Paylan (\%) (1970-2018) (ETKB, 2020). 1970-2018 Enerji Denge Tablolari)

Sektörlerin enerji kullanımlarının milli gelir içerisindeki payları ile orantılı bir şekilde değişmemesi sektörlerdeki enerji yoğunluğunun farklılaşmasından kaynaklı olabilir. Üretilen her bir birim GSYIH başına kullanılan enerji miktarı olarak hesaplanan enerji yoğunluğunun zamandaki değişimi doğrusal değildir, tersine çevrilmiş $\mathrm{U}$ şeklinde bir eğri oluşturur ve tipik olarak gelişme aşamasında artar ve gelişmiş aşamada ise azalma eğilimine girer (Ediger, 2008, s. 85). Türkiye'de sektörlerin her bir üretim sürecindeki enerji yoğunluklarının nasıl seyir izlediğine Şekil 3’te yer verilmiştir. Buna göre, enerji yoğunluğunun tarım sektöründe 1980 yllından 2009 yllına kadar arttığını 2009 yllından itibaren istikrarlı bir seyir izlediğini, sanayi sektöründe enerji yoğunluğunun ortalama olarak \%10 seviyeleri ile hep aynı trendde olduğunu söylemek mümkündür. Diğer taraftan konut ve hizmetler sektöründe enerji yoğunluğunun 1970 lerde \%10 düzeylerinde iken 2017 yllına gelindiğinde bu oranın \%3'e kadar gerilediğini ve enerji yoğunluğundaki kısmi azalışlara rağmen en büyük dalgalanmaların ulaştırma sektöründe ortaya çıktığı gözlemlenmektedir. Bu gözlemler kapsamında Türkiye ekonomisinin tarımdan sanayiye dönüşümünün bir sonucu olarak bazı sektörlerde enerji yoğunluğunun bir miktar iyileştiğini, özellikle hizmetler sektöründe enerji yoğunluğunun belirgin bir şekilde düştüğünü söylemek mümkündür. Ancak diğer sektörlerde gözlemlenen enerji yoğunluğundaki dalgalanmalar ekonominin halen gelişme aşamasında olduğuna işaret etmektedir.

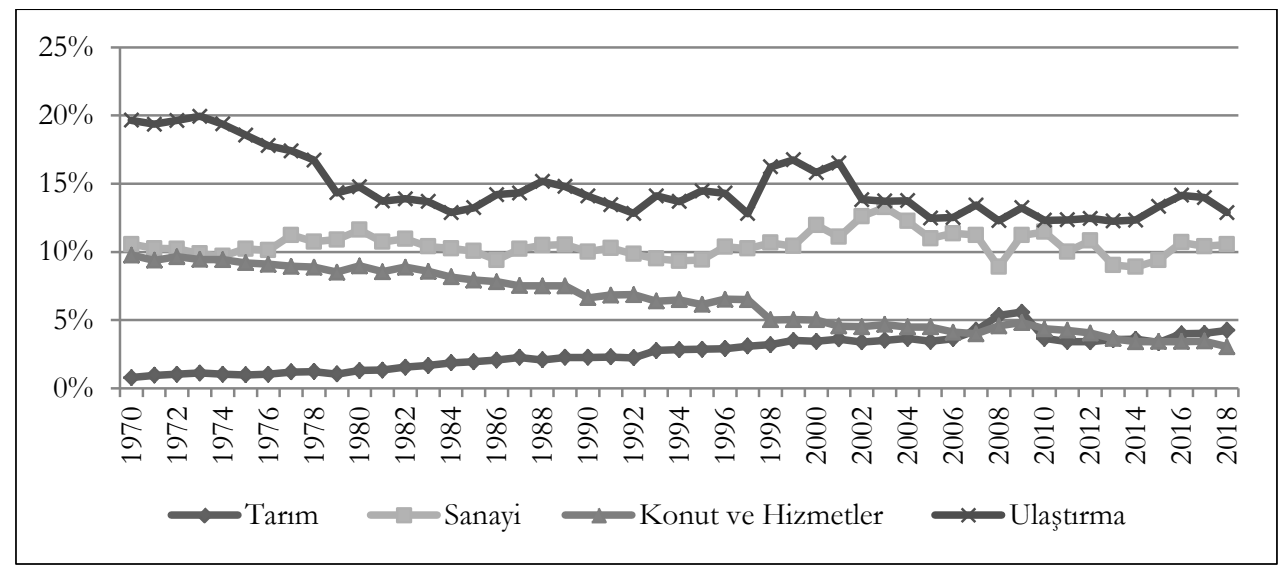

Şekil 3. Sektörlerin Toplam Enerji Yoğunluklar (\%) (1970-2018), (ETKB (2020) 1970-2018 Enerji Denge Tablolar ve TÜIKK (2020)'den alman verilerle hesaplanmıștur).

Bu gelişmeler kapsamında Türkiye'de sektörlerin enerji kullanımlarının enerji yoğunluğu ve milli gelir içerisindeki paylarına bağlı olarak farklılaştığı söylenebilir. Enerji ihtiyacını yüksek oranda fosil yakıtlardan karşılayan ve enerjide dışa bağımlılığı giderek artan Türkiye'de arz güvenliği sorunun önüne geçilebilmesi 
için geliştirilecek politikalarda enerjinin sektörel kullanımında hangi faktörlerin etkili olduğunun ve bu faktörlerin etki derecesinin saptanması büyük önem taşımaktadır. Bu motivasyondan hareketle bu çalışmada, literatürdeki çalışmalardan farklı olarak sektörel enerji kullanımları tarım ve sanayi sektörünün yanında hizmetler sektörü de kendi içerisinde konut ve ulaştırma olarak ayrıştırılarak incelenmektedir. Böylelikle temel sektörler yanında hizmetler sektörü içerisinde büyük payı bulunan konut ve ulaştırma sektörlerindeki enerji kullanımlarının altında yatan itici faktörleri tespit ederek sektörel enerji politikalarının belirlenmesi sürecine katkıda bulunmak hedeflenmektedir.

\section{Ampirik Literatür}

Ayrıştırma analizi, 1973 dünya enerji krizinin ardından enerji tüketim kalıpları ve enerji tüketimindeki değişikliklerin altında yatan itici faktörleri anlamak ihtiyacıyla kullanılmaya başlanmıştır. Bugün ise, çevre alanında enerji kullanımı, enerji yoğunluğu veya enerji ile ilgili sera gazı emisyonları gibi göstergelerdeki değişiklikleri analiz etmek için yaygın olarak kullanılmaktadır (Granel, 2003, s. 1-7). Bu kapsamda enerji kullanımının ayrıştırılması ile ilgili yapılan temel ampirik çalışmaların bulgularına aşağıda yer verilmektedir.

Ediger ve Huvaz (2006) çalısmalarında, 1980-2000 dönemi için Türkiye ekonomisinde tarım, sanayi ve hizmetler sektöründeki enerji kullanımını incelemişlerdir. LMDI yönteminin kullanıldığı çalışmada; birincil enerji tüketimi ile GSYİH arasında yakın bir ilişki olmasına rağmen; 1982, 1988-1989, 1994 ve 1998-2000 dönemlerinde sektörel enerji kullanımında önemli farklllıklar olduğu bulgusuna ulaşılmıştır.

Achao ve Schaeffer (2009) çalısmalarında, 1980-2007 döneminde Brezilya'da konut elektriğindeki değişimlerin kaynaklarını ayrıştırma analizi ile incelemişlerdir. LMDI yönteminin kullanıldığı çalışmada, analiz sonuçları Brezilya konut sektöründe elektrik tüketiminde gözlenen değişikliklerin esas olarak incelenen dönemde tüketici sayısındaki artıştan (pozitif çıktı etkisi) ve hanelerdeki spesifik elektrik tüketimindeki değişikliklerden (yoğunluk etki) kaynaklı olduğunu göstermiştir.

Yılmaz ve Atak (2010) çalısmalarında, Türkiye'de 1980-2005 yılları arasında sektörel enerji tüketimini analiz etmişlerdir. Tarım, sanayi, hizmet ve ulaşım sektörlerinin ayrı ayrı ele alındığı çalışmada enerji kullanımları Se-Hark Park'ın ayrıştırma yöntemi ile incelenmiştir. Analiz sonuçları, sektörlerdeki enerji tüketimini etkileyen en önemli faktörün çıtı etkisi olduğunu, enerji yoğunluğunun ise enerji tüketimini olumsuz etkilediğini göstermiştir.

Chung, Kam ve Ip (2011) çalışmalarında, 1990-2007 döneminde Hong Kong'da konutlardaki enerji kullanımını LMDI yöntemi ile ayrıştırmışlardır. Ampirik bulgular, yapısal etki ile kıyaslandığında yoğunluk etkisinin konut sektörünün enerji verimliliğini daha çok etkilediğini göstermiştir.

Zhang, Li, Zhou ve Mu (2011) çalışmalarında, 1980-2006 döneminde Çin'de ulaşım sektöründe enerji tüketimindeki değişiklikleri etkileyen faktörleri tespit etmek amacıyla LMDI tekniğini kullanmışlardır. Elde edilen bulgular, ulaşım sektöründe enerji tüketiminin artmasında en önemli katkının çıktı etkisi olduğunu ve enerji tüketiminin azaltılmasında enerji yoğunluğu etkisinin baskın rol oynadığını göstermiştir.

Nie ve Kemp (2014) çalışmalarında, 2002-2010 döneminde Çin'de konut enerji kullanımındaki değişiklikleri LMDI ayrıştırma analizi ile incelemişlerdir. Ampirik bulgular, enerji kullanan cihazlardaki artışın konut enerji tüketimindeki artışa en büyük katkı sağladığını ve nüfusun konut enerji kullanımı üzerinde en düşük etkiye sahip faktör olduğunu göstermiştir.

Yılmaz, Kelleci ve Bostan (2016) çalışmalarında, 1970-2013 döneminde Türkiye'de sektörel enerji tüketimini LMDI'nın toplamsal tipte ayrıştırma analiz versiyonuile incelemişlerdir. Ampirik bulgular, incelenen dönemde sektörel enerji tüketiminin çıktı ve yapısal etki nedeniyle arttığını, yoğunluk etkisi nedeniyle ise düştügünü göstermiştir.

Kim ve Heo (2016) çalışmalarında, Kore'de 1985-2005 döneminde enerji kullanımındaki yapısal değişimin kaynaklarını yapısal ayrıştırma modelini kullanarak analiz etmişlerdir. Ampirik bulgular, $1995^{\prime}$ ten 2005'e kadar enerji kullanımında belirgin bir yapısal etki olduğunu göstermiştir.

Karimu, Brännlund, Lundgren ve Söderholm (2017) çalışmalarında, 1990-2008 döneminde İsveç’te sanayi sektöründeki 14 alt bileşenin enerji yoğunluğunun belirleyicilerini analiz etmişlerdir. Laspeyres ve Paasche indekslerinin geometrik bir ortalaması olan Fisher indeks ayrıştırma yaklaşımının kullanıldığ1 çalışmada, enerji fiyatı da dâhil olmak üzere girdi fiyatlarının, İsveç sanayi alt sektörlerindeki enerji yoğunluğunun en önemli belirleyicisi olduğu bulgusuna ulaşılmıştır. 
Reuter, Patel ve Eichhammer (2019) çalışmalarında, 2000-2015 döneminde Avrupa Birliği (AB-28) ülkelerinde nihai enerji tüketimindeki değişiklikleri yönlendiren faktörleri araştırmışlardır. LMDI metodolojisinden faydalanılan çalışmada, $\mathrm{AB}$ (28)'deki nihai enerji tüketimindeki düşüşün esas olarak sanayideki enerji verimliliği artışından ve ardından hane halkları enerji kullanımından kaynaklı olduğu bulgusuna ulaşılmışır.

Moreau, Neves ve Vuille (2019) çalş̧malarında, 1990-2014 döneminde Avrupa Birliği'ndeki enerji tüketimini düşürmede yapısal değişikliklerin rolünü ve enerji verimliliği önlemlerinin etkinliğini ölçmeyi hedeflemişlerdir. LMDI yönteminden faydalanılan çalışmada, enerji tüketimindeki azalmanın önemli bir kısmının sanayisizleştirme gibi yapısal değişikliklerle ve enerji verimliliğindeki artışlarla ilgili olduğu bulgusuna ulaşılmıştır.

Akyürek (2020) çalışmasında, 2005-2014 döneminde Türk imalat endüstrisinin toplam enerji tüketimi artışını çıktı etkisi, yapı etkisi ve yoğunluk etkisi açısından ayrıştırarak incelemiştir. LMDI yönteminin kullanıldığı çalışmada analiz sonuçları, çıktı etkisinin enerji tüketimine önemli bir katkısı olduğunu ortaya koyarken, yap1 ve yoğunluk etkilerinin önemsiz olduğunu göstermiştir. Öte yandan, enerji yoğun endüstriler için, yapısal ve yoğunluk etkilerinin eş zamanlı olarak ortaya çıktığı da ulaşılan bulgular arasindadir.

Kazemi ve Hosseinzadeh (2020) çalş̧malarında, 2001-2011 döneminde İran'da enerji tüketimindeki değişikliklerin nedenlerini araştırmışlardır. Girdi-Çıktı Yapısal Ayrıştırma Analizi’nin kullanıldığı çalışmada, enerji kullanımındaki artışı ana itici güçlerinin yatırım düzeyindeki artış ve hane halkı tüketimi olduğu ve yapısal değişikliklerin enerji kullanımının artmasına neden olduğu bulgusuna ulaşılmıştır.

Kulionis ve Wood (2020) çalışmalarında, 1970-2009 dönemi için 27 Avrupa Birliği ülkesi ve diğer 13 gelişmiş ve gelişmekte olan ekonomilerden oluşan yüksek gelirli ülkelerde enerji ayak izindeki değişikliklere katkıda bulunan ana faktörleri incelemişlerdir. Leontief tarafından geliştirilen çevresel olarak genişletilmiş girdi-çıktı analizine dayalı yapısal ayrıştırma analizinin kullanıldığı çalışmada sonuçlar, enerji ayak izindeki değişikliklerin enerji yoğunluğundaki düşüş ve kişi başına tüketimdeki artış olmak üzere temel olarak iki itici güç tarafindan yönlendirildiğini göstermiş̧ir.

Literatürde sektörel ya da bölgesel düzeyde doğrudan enerji kullanımlarının altında yatan faktörlerin analiz edildiği bu çalışmaların yanı sıra dolaylı olarak enerji kaynaklı karbondioksit $\left(\mathrm{CO}_{2}\right)$ emisyonlarının ayrıştırıldığ1 çalışmalara da rastlanmaktadır. Bu çalışmalara örnek olarak; Lise (2006), Tunç, Türüt-Aşık ve Akbostanc1 (2009), Akbostanc1, Tunç ve Türüt-Aşık (2011), Kumbaroğlu (2011), Hammond ve Norman (2012), Alves ve Moutinho (2013), Moutinho, Moreira ve Silva (2015), Zhang, Dai ve Song (2015), Fan ve Lei (2016), Zhang, Wang ve Zheng (2018), Jia, Jian, Xie, Gu ve Chen (2019), Hastuti, Hartono, Putranti ve Imansyah (2020), Taka, Huong, Shah ve Park (2020)'nin çalışmaları gösterilebilir.

\section{Veri ve Yöntem}

Türkiye'de 1970-2018 döneminde tarım, sanayi, konut ve hizmetler ve ulaştırma sektörlerindeki enerji kullanımlarının alt dinamiklerinin araştırıldığı çalışmada; sektörlerin yarattıkları katma değerler diğer bir ifade ile sektörel GSYIHH değerleri TÜiK (2020) veri tabanından (zincirlenmiş hacim endeksi olarak Bin TL cinsinden), sektörel enerji kullanım verileri ise ETKB (2020) Denge Tabloları (1970-2018)'ndan (bin ton eşdeğer petrol (btep) cinsinden) temin edilmiştir.

Enerji çalışmalarında ayrıştırma analizinin temel amacı, zaman içerisinde enerji ve çevresel göstergelerdeki değişikliklere katkıda bulunan faktörleri ölçmektir. Bu amaçla, enerji literatüründe en sık kullanılan iki yöntem Laspeyres İndeks Metodu ve bir aritmetik ortalama ağıllı fonksiyonu kullanan Divisia İndeks Metodu'dur. Ancak bu iki analizde iki temel problem ortaya çıkmaktadır. Bunlardan ilki, ayrışma sonucunda bir kalıntının (artık terim) varlığıdır. Bu kalıntı, Laspeyres indeks yöntemi durumunda genellikle büyüktür ve bubüyük kalıntı ayrışma amacını ortadan kaldırmaktadır çünkü bu, ayrıştırılan enerji göstergesinde gözlemlenen değişikliğin büyük bir kısmının açıklanmadan bırakıldığı anlamına gelmektedir. İkinci problem ise, veri setindeki sıfır değerleridir. Veri seti sıfır değerleri içerdiğinde, bir aritmetik ortalama ağırlık fonksiyonu ile Divisia indeks yönteminin uygulanmasında hesaplama problemleri ortaya çıkabilmektedir (Ang ve Choi, 1997, s. 60; Ang, Zhang ve Choi, 1998, s. 489). Bu problemleri ortadan kaldırmak amaciyla Ang ve Choi (1997), denklemlerdeki aritmetik ortalama ağıllk fonksiyonu yerine logaritmik ortalama ağırlık fonksiyonu kullanan çarpımsal forma dayalı rafine bir Divisia yöntemi önermiştir (Ang ve Zhang, 2000, s. 1163). LMDI adı verilen bu yöntemin uygulama açısından pek çok 
avantajı bulunmaktadır. İlk olarak, LMDI mükemmel bir ayrıştırma sağlamaktadır, diğer bir ifadeyle sonuçlar açılanamayan bir artık terim içermediğinden bu durum sonuçların yorumlanmasını basitleştirmektedir. İkinci olarak, çarpımsal LMDI tarafından verilen sonuçlar toplandığında toplam etkiyi verme özelliğine sahiptir. Üçüncü olarak çarpımsal ve toplamsal ayrıştırma arasında basit bir fonksiyonel ilişki bulunmaktadır ve son olarak bu yöntem kümelenmede tutarlıdır (Ang, 2005, s. 870).

Çarpımsal ve toplamsal ayrıştırma arasındaki seçim metodolojik olarak önemsizdir ve farklılıklar sonuçları sunum ve yorumlama kolaylığında yatmaktadır. Ayrıştırma, bir dönem boyunca yıllık bazda yapıldığında, çarpımsal yaklaşımı kullanmak daha uygundur, çünkü genellikle endekslerde verilen ayrışırma sonuçları zaman içinde uygun bir şekilde gözlemlenebilmektedir (Ang ve Zhang, 2000, s. 1169). Bu çalışmada, sektörel enerji kullanımlarındaki değişikliklerin altında yatan temel faktörlerin belirli bir dönem içerisindeki seyrini gözlemlemek amaçlandığından diğer bir ifade ile bir zaman serisi uygulaması olduğundan ve yöntemin söz konusu pek çok avantajı bulunduğundan LMDI yönteminin toplamsal tipte ayrıştırma indeks versiyonu tercih edilmiştir. Böylelikle, bu yöntem sektörlerdeki enerji kullanımlarında çıktı, yapısal ve yoğunluk etkileri nedeniyle ortaya çıkan değişmelerin birbirini izleyen her yıl için ayrıştırılmasına olanak sağlamışır.

Toplam ayrıştırma analizi, $\mathrm{n}$ farklı sektör için toplam etki ( $\Delta$ Etot) olarak da adlandırılan, 0 yilından $\mathrm{t}$ yılına kadar Et-Eo olmak üzere hesaplanan toplam birincil enerji kullanımındaki değişimin kaynaklarını ölçmektedir. Bu kapsamda toplam etkiyi ( $\Delta$ Etot); sektörel üretimdeki değişiklik (yani çıtı etkisi $\Delta$ Epdn), üretim yapısındaki değişiklik (yani yapısal etki $\Delta$ Estr) ve sektörel enerji yoğunluğundaki değişiklik (yani yoğunluk etkisi $\Delta$ Eint) ve artık etki ( $\Delta$ Ersd) şeklinde ayrıştırmak mümkündür (Ang vd., 1998, s. 490):

$$
\Delta E_{\text {tot }}=\Delta E_{\text {pdn }}+\Delta E_{\text {str }}+\Delta E_{\text {int }}+\Delta E_{\text {rsd }}
$$

Tahmin edilen etkilerin toplamı, gözlemlenen $\Delta$ Etot'a tam olarak eşit olmadığında kalan etkiler $\Delta$ Ersd şeklindeki bir kalıntı etkisi olarak açıklanmaktadır. Ancak kalıntı etkisi gözlemlenen değişikliğin büyük bir kısmını açıklayamamak anlamına geldiğinden LMDI yönteminin uygulamasında kalıntı etkisi ortadan kaldırılmıştır. Dolayısıyla bu çalışma için $\Delta$ Ersd $=0$ 'dır ve denklem şu şekilde yeniden yazılabilir:

$$
\Delta E_{\text {tot }}=\Delta E_{\text {pdn }}+\Delta E_{\text {str }}+\Delta E_{\text {int }}
$$

2 no’lu denklemde yer verilen bu üç etkiyi hesaplamak için kullanılan modeller aşağıdaki gibidir:

$$
\begin{aligned}
& \Delta E_{p d n}=\sum_{i} L\left(E_{i, t}, E_{i, 0}\right) \ln \left(Y_{t} / Y_{0}\right) \\
& \Delta E_{\text {str }}=\sum_{i} L\left(E_{i, t}, E_{i, 0}\right) \ln \left(S_{i, t} / S_{i, 0}\right) \\
& \Delta E_{\text {int }}=\sum_{i} L\left(E_{i, t}, E_{i, 0}\right) \ln \left(I_{i, t} / I_{i, 0}\right)
\end{aligned}
$$

Burada 0 ve $\mathrm{t}$ incelenen dönemi göstermekle birlikte, Ei, i sektörünün btep cinsinden birincil enerji kullanımını, Y; sektörlerin bin TL cinsinden GSYİH'sını, Si; i sektörünün üretim içerisindeki payını (Yi/Y) ve Ii; i sektörünün btep/TL cinsinden enerji yoğunluğunu (Ei/Yi) ifade etmektedir.

Denklem 3,4 ve 5 'te yer verilen $L\left(E_{i, t}, E_{i, 0}\right)$ şu şekilde hesaplanmaktadır:

$$
L\left(E_{i, t}, E_{i, 0}\right)=\left(E_{i, t}-E_{i, 0}\right) /\left(\ln \left(E_{i, t} / E_{i, 0}\right)\right)
$$

Burada $E_{i, t} \rightarrow E_{i, 0}$ 'a giderken $L\left(E_{i, t}, E_{i, 0}\right)$ '’n limiti $L\left(E_{i, t}, E_{i, 0}\right)=E_{i, t}$ 'ye eşittir. Bu metodolojiden hareketle her bir sektör i (tarım, sanayi, konut ve hizmetler, ulaştırma) için çıtı, yapısal ve yoğunluk etkilerinin payları 3,4 ve 5 numaralı denklemler kullanılarak hesaplanmışır ve ampirik bulgulara bir sonraki bölümde yer verilmiştir.

\section{Bulgular}

Sektörler bazında enerji kullanımlarının alt dinamiklerine yer vermeden önce incelenen dönemde Türkiye'nin toplam enerji kullanımında hangi etkilerin ön planda olduğu ülkenin yapısal dönüşümleri dikkate alınarak ayrıştırlmıştır. Bu kapsamda ülkede kapalı planlı dönemin hâkim olduğu 1970-1979 dönemi, dışa açık büyüme anlayışının benimsendiği 1980-1999 dönemi ve sürdürülebilir büyüme hedefinin benimsendiği 2000'den günümüze kadar olan dönem ayr1 ayr1 olarak incelenerek, söz konusu dönemlerdeki enerji kullanımlarının üzerindeki çıktı, yapısal ve yoğunluk etkileri hesaplanmış ve bulgulara Tablo 1'de yer verilmiştir. 
Tablo 1. Türkiye'de Toplam Birincil Enerji Kullanmmmn Toplu Ayrıștırma Analizi (btep) (1970-2018)

\begin{tabular}{ccccc}
\hline Dönem & C1kt Etkisi & Yap1sal Etki & Yoğunluk Etkisi & Toplam Etki \\
\hline $1970-1979$ & 9592.5 & 311.97 & -65.4996 & 9838.97 \\
$1980-1999$ & 31477.31 & 199.5625 & -2731.31 & 28945.56 \\
2000-2018 & 71907.2 & -1344.48 & -18251.2 & 52311.52 \\
Toplam (1970-2018) & 112977 & -832.947 & -21048 & 91096.05 \\
\hline
\end{tabular}

Toplam ayrıştırma analizi bulguları, incelenen tüm dönem boyunca Türkiye'de toplam enerji kullanımının 91.096 btep arttı̆̆ını, bu artışa en büyük katkının her dönem ortalamasında çıktı etkisinden geldiğini ve diğer iki etkinin katkılarının sınırlı seviyelerde olduğunu göstermektedir. Toplam enerji kullanımının en büyük tetikleyicisi olan üretimdeki artışa paralel olarak artan çıktı etkisi 1979, 1980, 1994, 1999, 2001, 2009 ve 2018 dönemleri hariç bütün dönemlerde pozitiftir. Çıktı etkisi özellikle kriz dönemlerinde ortalama üretimin düşmesi nedeniyle negatif değerler almıştır. Yapısal etki incelenen dönem boyunca 22 yılda, yoğunluk etkisi ise yine incelenen dönem boyunca 27 yllda negatif değerler almıştır. Bu dönemlerin etkilerinin daha ayrıntılı görülebilmesi amacıyla tüm dönemlerin etki ayrıştırma sonuçlarına Ek Tablo 1'de yer verilmiştir. Yapısal dönüşümlerin daha hızlı yaşandığ1 1970-1979 ve 1980-1999 dönemlerinde enerji kullanımlarındaki yapısal etkinin pozitif olduğunu ancak 2000'li yıllardan itibaren sektörel dönüşümlerin yavaşlamasıyla bu etkilerin enerji kullanımını düşürücü etki yarattı̆̆ını söylemek mümkündür. Bir birim üretim yapmak için gereken enerji miktarının genel olarak bütün dönemler boyunca azalması sebebiyle ise yoğunluk etkisi her dönemde toplam enerji kullanımını düşürücü bir etki yaratmıştır. Çıktı, yapısal ve yoğunluk etkilerinin sektörel bazdaki enerji kullanımları üzerinde nasıl değişim gösterdiğini gözlemlemek amacıyla sektörel enerji kullanımlarına her bir etkinin katkısı önce tüm dönem dikkate alınarak daha sonra da yıllar itibarıyla ayrı ayrı ayrıştırılmıştır.

Tablo 2. Türkiye'de Sektörel Eneriji Kullanmmnn Ayrıștorma Analizi (btep) (1970-2018)

\begin{tabular}{lcccc}
\hline Sektörler & Çוktı Etkisi & Yap1sal Etki & Yoğunluk Etkisi & Toplam Etki \\
\hline Tarım & 1071.4376 & -4085.69 & 2999.562439 & -14.68995 \\
Sanayi & 32729.65 & -6084.32 & -696.65 & 25948.68 \\
Konut ve Hizmetler & 49340.25 & 8327.072 & -24698.2 & 32969.07 \\
Ulaştırma & 28318.13 & 3491.033 & -3085.13 & 28724.03 \\
Toplam & 111459.5 & 1648.091 & -25480.5 & 87627.09 \\
\hline
\end{tabular}

Sektörel enerji kullanımlarında çıktı, yapısal ve yoğunluk etkilerinin paylarının yer verildiği Tablo 2'ye göre incelenen tüm dönemde bütün sektörlerde çıktı etkisinin pozitif olduğu gözlemlenmektedir. Diğer bir ifadeyle bütün sektörlerde artan üretim enerji kullanımlarını da arttırmış ve toplam etkiye en büyük katkıyı sağlamıştır. Bu durum Şekil 1 ve Şekil 2'de yer verilen sektörlerin GSYİH içerisindeki payları ve enerji kullanımlarının sektörel dağılım grafikleri ile de doğrulanmaktadır. Yapısal etki, yine yapısal dönüşümlere paralel olarak tarım ve sanayi sektörünün milli gelir içerisindeki payının azalması nedeniyle bu sektörlerde enerji kullanımını azaltıcı rol oynarken, konut ve hizmetler ile ulaştırma sektörünün milli gelir içerisindeki paylarının artmasına paralel olarak enerji kullanımlarının artmasına yol açmıştır. Yoğunluk etkisi ise, tarım sektörü dışında diğer bütün sektörlerde enerji kullanımlarının azalmasına katkı sağlamıştır. Şekil 3’te de yer verilen verilerle tutarlılık taşıyan ve daha az enerji kullanarak aynı çıtıyı üretmek ya da aynı enerji miktarı ile daha fazla çıktı üretmek anlamına gelen bu gelişme sektörler bazında enerjinin daha verimli kullanıldığının bir göstergesi olarak yorumlanabilir. Sektörler bazındaki enerji kullanımları üzerindeki bu etkilerin her bir dönem boyunca nasıl seyir izlediğine Şekil 4, 5, 6 ve 7'de yer verilmiştir.

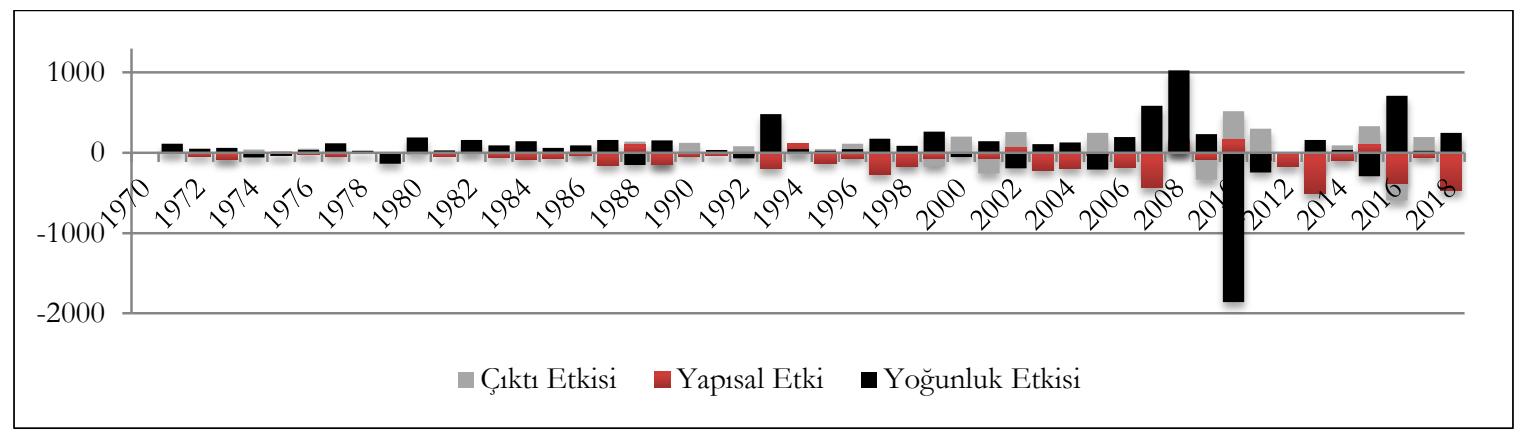

Şekil 4. Tarm Sektörü Enerji Kullanmı Ayrşstıma Analiz Bulgular (btep) (1970-2018) 
Şekil 4'te yer verilen tarım sektörüayrıştırma bulguları incelendiğinde; tüm dönemler boyunca enerji kullanımının en önemli dinamiğinin yoğunluk etkisi olduğu göze çarpmaktadır. Tüm dönem boyunca çıktı etkisi 18 yılda, yapısal etki 37 yılda, yoğunluk etkisi ise 13 yılda negatif değerler alarak tarım sektörü enerji kullanımını düşürücü etki yaratmıştır. Dönemlere ayrılarak incelendiğinde ise çıktı etkisi her dönemde enerji kullanımını artırmakla birlikte en büyük etkiye 2000-2018 döneminde 886.38 btep artış ile neden olmuştur. Çıktı etkisi sektörün enerji kullanımını 1970-1979 döneminde 102.961 btep, 1980-1999 döneminde ise 82.091 btep artırmışır. Yapısal etki ise tüm dönemlerde enerji kullanımını düşürücü etki yaratmakla birlikte bu etki 1970-1979 döneminde -197.393 btep, 1980-1999 döneminde -1376.88 btep, 2000-2018 döneminde -2511.43 btep olmuştur. Yoğunluk etkisi ise her dönemde enerji kullanımını artıran en önemli faktör olmakla birlikte bu artış 1970-1979 döneminde 184.039 btep, 1980-1999 döneminde 2043.908 btep ve 2000-2018 döneminde 771.615 btep olmuştur.

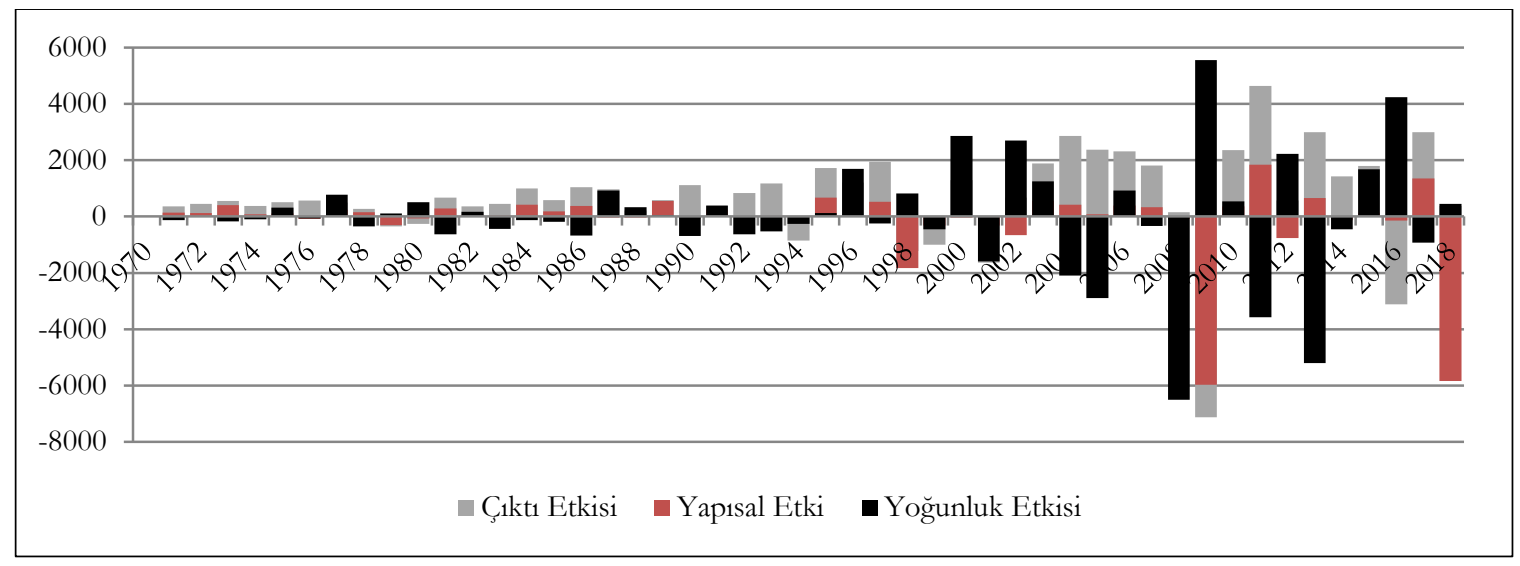

Şekil 5. Sanayi Sektörü Enerij Kullanmı Ayrşstrma Analiz Bulgular (btep) (1970-2018)

Sanayi sektörü enerji kullanımı ayrıştırma bulgularına yer verilen Şekil 5'e göre, incelenen dönem boyunca çıtkı etkisi 8 yılda, yapısal etki 19 ylda, yoğunluk etkisi ise 26 yılda negatif değerler alarak enerji kullanımını azaltıcı etki yaratmıştır. Böylelikle sanayi sektöründe enerji kullanımını arttıran en önemli itici faktörün çıktı etkisi olduğunu söylemek mümkündür. Dönem ortalamalarına bakıldığında çıktı etkisi her dönemde sektörün enerji kullanımlarını arttırmakla birlikte en yüksek artış 2000-2018 döneminde 18606.98 btep ile gerçekleşmiştir. Yine çıktı etkisi 1970-1979 döneminde 3233.302 btep artışa, 1980-1999 döneminde ise 10889.37 btep artışa neden olmuştur. Yapisal etki sektörün enerji kullanımını 1970-1979 döneminde 851.660 btep, 1980-1999 döneminde 961.155 btep artırırken, 2000-2018 döneminde sektörün milli gelir içerisindeki payının düşmesiyle birlikte enerji kullanımını -7897.14 btep azaltmıştır. Yoğunluk etkisi ise sektörün enerji kullanımını 1970-1979 döneminde 360.698 btep, 1980-1999 döneminde 129.632 btep arttırken, 2000-2018 döneminde -1186.98 btep azaltmıştır.

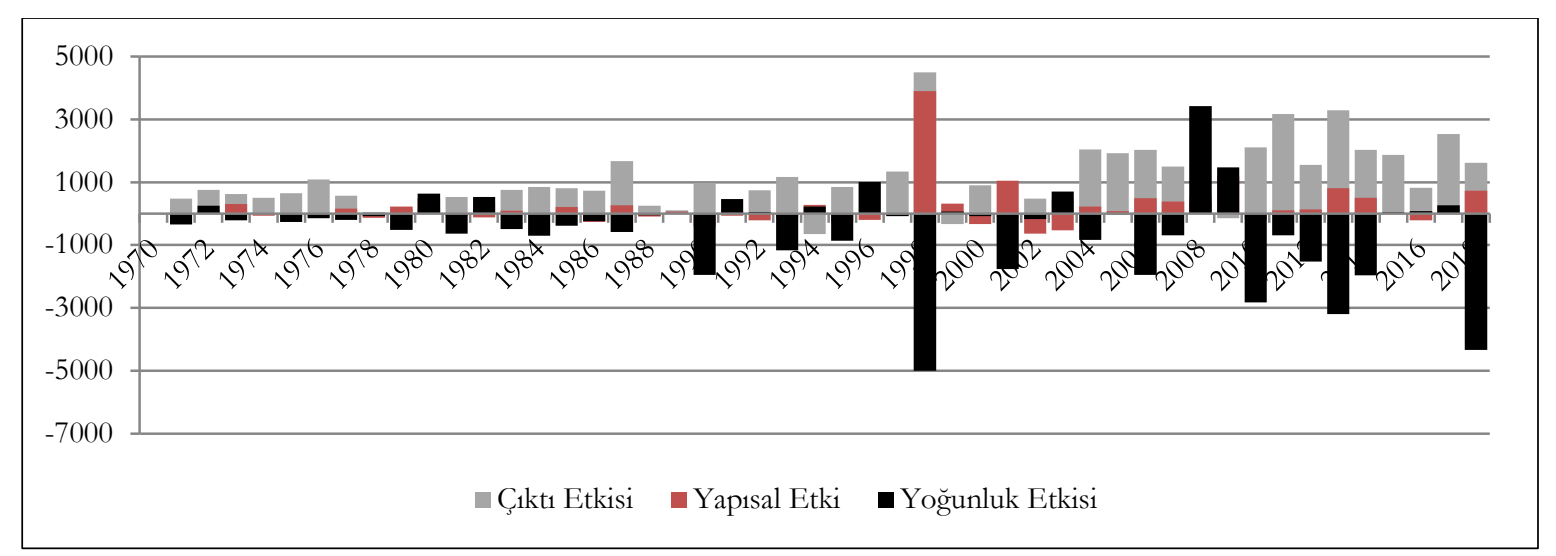

Şekil 6. Konut ve Hiæmetler Sektörü Enerji Kullanmı Ayrștrrma Analiz Bulgular (btep) (1970-2018)

Konut ve hizmetler sektörü enerji kullanımı ayrıştırma etkilerine yer verilen Şekil 6'da, enerji kullanımında en büyük itici gücün sanayi sektöründe olduğu gibi genel olarak her dönemde çıktı etkisi olduğu görülmektedir. Çıktı etkisi 1994, 1999, 2001 ve 2009 kriz dönemleri hariç her dönemde pozitif değerler alarak sektörün enerji kullanımını arttırmıştır. Yapısal etki dönem boyunca 22 yılda, yoğunluk 
etkisi ise 33 yıl boyunca negatif değerler alarak sektörün enerji kullanımını azaltıcı etki yaratmıştır. Dönem ortalamalarına göre değerlendirildiğinde ise, çıktı etkisi her dönemde enerji kullanımını arttırmasına rağmen en yüksek artış 28619.84 btep artış ile 2000-2018 döneminde gerçekleşmiş, onu sırasıyla 15841.97 btep artış ile 1980-1999 dönemi ve 4878.438 btep artış ile 1970-1979 dönemi izlemiştir. Çıktı etkisinde olduğu gibi yapısal etki de konut ve hizmetler sektörü enerji kullanımını arttırıcı bir etki yaratmıştır. Yapısal etki de en belirgin artışlar 2000-2018 döneminde 4216.51 btep'lik artışla yaşanırken, onu sırasıyla 3684.683 btep'lik artışla 1980-1999 dönemi ve 425.871 btep'lik artışla 1970-1979 dönemi izlemiştir. Yoğunluk etkisi ise söz konusu bu iki etkinin tersine tüm dönem ortalamalarında sektörün enerji kullanımının azalmasına katkı sağlamıştır. Bu azalış 1970-1979 döneminde -1522.44 btep, 1980-1999 döneminde -9118.97 btep iken 2000-2018 döneminde -14056.8 btep olmuştur.

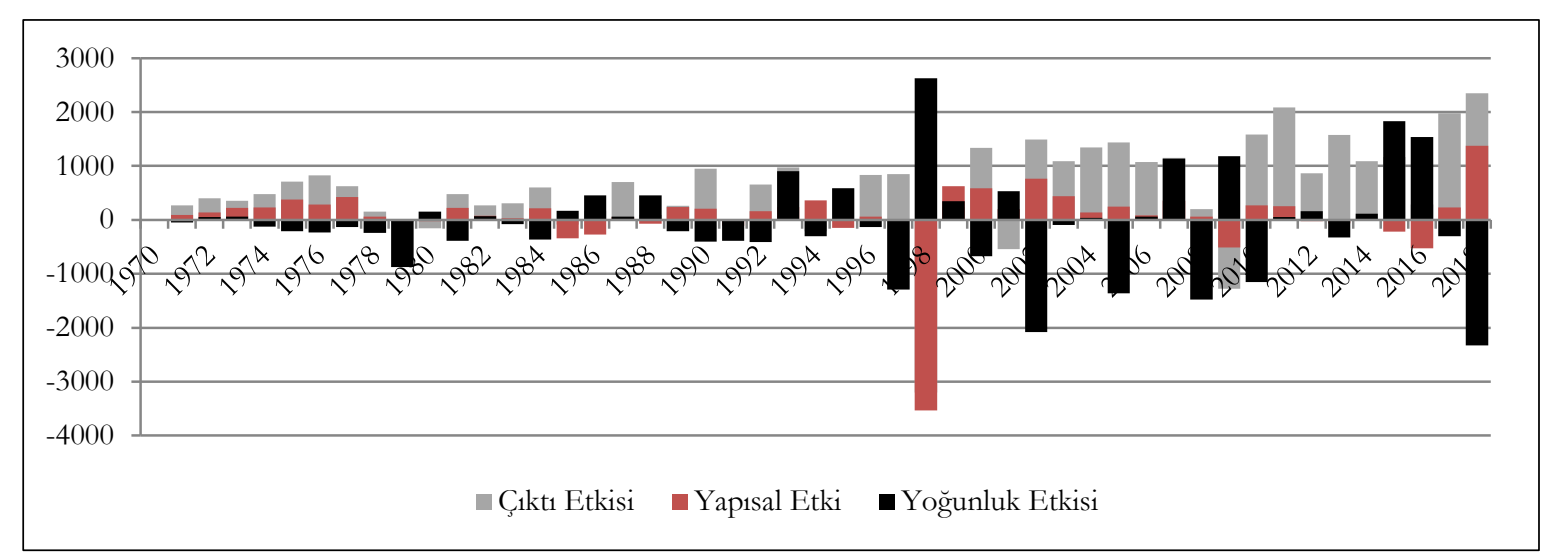

Şekil 7. Ulaştırma Sektörü Enerji Kullanım Ayrşstırma Analiz. Bulgular (btep) (1970-2018)

Şekil 7'de yer verilen ulaştırma sektörü ayrıştırma bulguları, incelenen dönemde genel olarak sektörün enerji kullanımını en fazla artıran etkinin çıktı etkisi olduğu ve onu yapısal etkinin izlediğine işaret etmektedir. İncelenen dönem boyunca çıktı etkisi özellikle kriz dönemlerinde olmak üzere 8 yılda, yapısal etki 13 yılda, yoğunluk etkisi ise 26 yılda negatif değerler alarak enerji kullanımını azaltıcı etki yaratmıştır. Dönem ortalamaları incelendiğinde ise çıktı etkisi, her dönemde sektörün enerji kullanımını artırmakla birlikte bu artış 1970-1979 döneminde 3781.20 btep, 1980-1999 döneminde 4275.572 btep ve 2000-2018 döneminde sektörün milli gelir içerisindeki payının artmasıyla birlikte 20261.35 btep olmuştur. Yapısal etki 1970-1979 döneminde sektörün enerji kullanımının 1827.96 btep ve 2000-2018 döneminde 3675.31 btep artmasına neden olurken, 1980-1999 döneminde enerji kullanımının -2012.26 btep azalmasına yol açmıştır. Yoğunluk etkisi ise yapısal etkinin tam tersine 1970-1979 döneminde sektörün enerji kullanımının -1757.21 btep ve 2000-2018 döneminde -3170.35 btep azalmasına, 1980-1999 döneminde ise enerji kullanımının 1842.428 btep artmasına yol açmıştır.

Konu ile ilgili ampirik literatürde Türkiye özelinde yapılan çalışmalarla kıyaslandığında; çalışmanın bulgular1 Ediger ve Huvaz (2006), Y1lmaz ve Atak (2010), Yllmaz vd. (2016) ve Akyürek (2020)'nin çalışmalarındaki bulgularla benzerlik taşımaktadır. İncelenen dönemde çıktı etkisinin toplam ve sektörel enerji kullanımı üzerindeki belirgin rolü, bu üç faktörün enerji kullanımları üzerindeki ortak etkisinin olumsuz bir seyir izlemesine neden olmaktadır. Diğer bir ifade ile, ülkede enerji verimliliği ve enerji tasarrufu politikalarının yeterli seviyede olmaması enerji yoğunluğunu düşürmeye yetmemektedir. Diğer taraftan, konu ile ilgili AB açısından yapılan çalışmalarda (Reuter vd., 2019; Moreau vd., 2019; Kulionis ve Wood, 2020) en çarpıcı ortak bulgu olarak, enerji kullanımını azaltmada enerji verimliliği iyileştirmelerinin giderek daha önemli hale geldiği vurgulanmaktadır. Bu çalısmalarla kıyaslandığında ise; Türkiye'nin enerji kullanımındaki dönüşümünü $\mathrm{AB}$ ile uyumlu hale getirmek için yaptığı yapısal reformlar kapsamında enerji verimliliği iyileştirmelerini enerji politikalarının merkezine yerleştirmek için daha fazla çaba harcaması gerektiği söylenebilir.

\section{Tartışma, Sonuç ve Öneriler}

Bu çalışma, 1970-2018 döneminde tarımsal ekonomiden sanayi ekonomisine, sanayi ekonomisinden hizmetler sektörüne doğru bir dönüşümün yaşandığı Türkiye'de sektörel enerji kullanımının alt dinamiklerini tespit etmeyi hedeflemiştir. Literatürde yaygın olarak kullanılan ve pek çok avantajı bulunan Logaritmik Ortalama Divisia İndeksi'nin toplamsal tipte ayrıştırma analizi versiyonundan faydalanılan 
çalışmada, hem ekonominin toplam enerji kullanımının hem de sektörel enerji kullanımlarının itici güçleri dönemler itibarıyla ayrıştırılarak incelenmiştir.

Genel olarak değerlendirildiğinde, toplam ve sektörel ayrıştırma analizi bulguları şu şekilde özetlenebilir: (i) İncelenen dönemde (1970-2018) Türkiye ekonomisinde birincil enerji kullanımının en önemli dinamiği çıtı etkisidir diğer bir ifade ile artan üretim bütün sektörlerde enerji kullanımının artmasına yol açmıştır. Bunun yanında incelenen dönem boyunca büyük oranda yapısal etki ve daha az miktarda ise yoğunluk etkisi enerji kullanımını azaltıcı rol oynamışıı. (ii) Benimsenen ekonomi politikaları dikkate alınıp Türkiye ekonomisi üç döneme ayrıldığında; 1970-1979 kapalı-planlı dönemde ve 1980-1999 dışa açı ekonomi modelinin benimsendiği dönemlerde çıktı etkisi ve yapısal etki enerji kullanımını artırırken, yoğunluk etkisi enerji kullanımını azaltmıştır. 2000'den günümüze kadar olan sürdürülebilir büyüme anlayışının benimsendiği dönemde ise diğer iki dönemden farklı olarak yalnızca çıktı etkisi enerji kullanımının artmasına yol açarken, yapısal etki ve yoğunluk etkisi enerji kullanımını düşürücü rol oynamıştır. (iii) Türkiye ekonomisinde toplam enerji kullanım modelindeki en belirgin değişiklikler 1979, 1994, 1999, 2001, 2008 ve 2009 yıllarında ortaya çıkmıştır ve bu dönemlerde meydana gelen değişmelerin doğrudan ekonomik krizlerle ilgili olduğu söylenebilir (iv) Sektörel açıdan bakıldığında, incelenen tüm dönem boyunca sektörel ayrışmada tarım sektörü hariç enerji kullanımının en önemli dinamiği çıtı etkisi olmuştur. Sektörlerdeki çıktı etkileri genellikle kriz dönemleri hariç enerji kullanımını arttırıcı bir etki yaratmışır. Diğer yandan tarım sektörü hariç yoğunluk etkisi diğer bütün sektörlerde enerji kullanımını düşürücü etki yaratmıştır. Yapısal etki ise tarım ve sanayi sektörlerinde enerji kullanımını düşürücü, konut ve hizmetler ve ulaştırma sektöründe enerji kullanımını artırıcı etki yaratmıştır. (v) Dönemler itibarılyla bakıldığında ise 1970-1979 ve 1980-1999 dönemlerinde tarım sektöründe enerji kullanımını tetikleyen en önemli faktör yoğunluk etkisi iken çıktı etkisi de sınırlı olmak koşuluyla enerji kullanımını artırmış, yapısal etki enerji kullanımını düşürücü etki yaratmıştır. 2000-2018 döneminde ise sektördeki enerji kullanımı büyük ölçüde çıktı etkisi ile ve daha az oranda yoğunluk etkisi ile artarken, yine yapısal etki nedeniyle azalmıştır. Sanayi sektöründe 1970-1979 ve 1980-1999 dönemlerinde enerji kullanımı her üç etki kanalıyla da artış gösterirken, en büyük etki çıktı kanalıyla ikinci olarak ise yapısal etki kanalıyla gerçekleşmiştir. 2000-2018 döneminde ise sektördeki enerji kullanımı çıktı etkisi ile artarken, yapısal etki ve yoğunluk etkisi kanaliyla azalmıştır. Konut ve hizmetler sektöründe 1970-1979, 1980-1999 ve 2000-2018 dönemlerinde sektördeki enerji kullanımı büyük ölçüde çıktı etkisi ile ve daha az oranda yapısal etki ile artarken, her üç dönem boyunca yoğunluk etkisi nedeniyle azalmıştır. Ulaştırma sektöründe ise 1970-1979 ve 2000-2018 dönemlerinde enerji kullanımı büyük ölçüde çıtı etkisi ile ve daha az oranda yapısal etki ile artarken, yoğunluk etkisi nedeniyle azalmıştır. 1980-1999 döneminde sektördeki enerji kullanımı ise yine çıtı etkisi ile büyük ölçüde ve yoğunluk etkisi ile sınırlı düzeyde artarken, yapısal etki nedeniyle azalmıştır.

$\mathrm{Bu}$ bulgular, ekonominin toplam enerji kullanımı açısından da sektörler açısından da enerji kullanımındaki artışın en önemli kaynağının üretim artışından kaynaklı çıktı etkisi olduğuna işaret etmektedir. Bunun yanında yoğunluk etkisi enerji kullanımını azaltıcı rol oynasa da bu etkinin çıktı etkisi yanında çok sınırlı seviyelerde kalması net enerji kullanımının belirgin seviyelerde artmasına engel olamamıştır. Ancak yine de yoğunluk etkisinin her dönemde tarım hariç diğer tüm sektörlerde enerji kullanımını düşürücü etki yaratması enerjinin verimli kullanıldığının göstermesi açısından olumlu bir gelişme olarak değerlendirilebilir.

Pek çok gelişmekte olan ülke gibi Türkiye'nin de öncelikli hedefi istikrarlı bir büyümenin sağlanmasıdır. Ancak üretim sürecinde ihtiyaç duyduğu enerjiyi $\% 80$ gibi büyük oranda fosil yakıtlardan sağlayan ve üstelik fosil yakıtlarda da yine yaklaşık $\% 80$ gibi yüksek düzeyde ithalata bağımlı bulunan Türkiye için çıktı etkisinin enerji kullanımı üzerinde bu kadar belirgin bir rol oynaması endişe vericidir. $\mathrm{Bu}$ durum hem enerji arz güvenliğinde bir risk oluşturması açısından (enerji arzında meydana gelen bir kesintinin çıtı üzerinde yaratabileceği olumsuz etki nedeniyle) hem de fosil yakıt kaynaklı emisyon artışını tetikleme ihtimali açısından pek çok yönüyle ekonomi üzerinde olumsuz etki yaratabilir. Bu kapsamda sektörel bazda uygulanacak politikalarla enerji yoğunluğunun düşüülmesi diğer bir ifade ile enerji verimliliğinin arttırılması kısa vadede müdahale edilebilecek en etkili araç olarak görünmektedir. Çünkü yapısal etki ve üretim artışı kaynaklı çıktı etkisine kısa vadede müdahale etmek ve üretim alışkanlıklarını değiştirmek güçtür. Ayrıca çıktı etkisine müdahale etmek büyüme üzerinde bask1 yaratabileceğinden politika yapıcılar açısından arzulanmayan bir araç olarak görülebilir. Yapısal dönüşüm sürecini henüz tamamlamamış olan ve halen erken kalkınma aşamasında olan Türkiye'nin enerji kullanımının gelecekte daha da artacağı senaryoları dikkate alındığında; sektörlerdeki enerji kullanımlarının tespit edilen bu dinamiklerinin enerji politikalarının tasarlanmasında kilit bir rol oynayabileceği düşünülmektedir. $\mathrm{Bu}$ 
tespitlerin yanı sıra, Türkiye ekonomisinin enerji-büyüme ilişkisini iyileştirmenin diğer önemli itici güçleri arasında, ülkenin enerji ihtiyacının büyük oranda fosil yakıtlardan değil yüksek potansiyeli bulunan yenilenebilir kaynaklardan sağlanması ve enerji arz kaynaklarının çeşitlendirilmesi, bunun için kamunun öncü özel sektörün destekleyici olduğu politikaların geliştirilmesi- izlenmesi ve hayata geçirilmesi, fosil yakıtlara (özellikle kömüre) verilen teşviklerin yerli ve özellikle yenilenebilir kaynaklara kaydırılarak finansman sağlanması, enerji tasarrufu sağlamanın bir aracı olarak teknolojik yeniliklere yönelinmesi ve enerjinin kullanımında çevre üzerinde yarattığı baskıların kontrol altında tutulması için her aşamada çevresel etki değerlendirmesinin (ÇED) dikkate alınması sayılabilir.

\section{Etik Beyan}

“Türkiye'de Sektörel Enerji Kullanımındaki Değģşimlerin Itici Gücleri: Aynşstrma Analiz̨?” başlıklı çalışmanın yazım sürecinde bilimsel kurallara, etik ve alıntı kurallarına uyulmuş; toplanan veriler üzerinde herhangi bir tahrifat yapılmamış ve bu çalışma herhangi başka bir akademik yayın ortamına değerlendirme için gönderilmemiştir. $\mathrm{Bu}$ araştırmada hazır veri seti kullanıldığı için etik kurul kararı zorunluluğu taşımamaktadır.

\section{Kaynakça}

Achão, C. ve Schaeffer, R. (2009). Decomposition analysis of the variations in residential electricity consumption in Brazil for the 1980-2007 period: Measuring the activity, intensity and structure Effects. Energy Policy, 37(12), 5208-5220.

Akbostanc1, E., Tunç, G. İ. ve Türüt-Aşık, S. (2011). $\mathrm{CO}_{2}$ emissions of Turkish manufacturing industry: A decomposition analysis. Applied Energy, 88(6), 2273-2278.

Akyürek, Z. (2020). LMDI decomposition analysis of energy consumption of Turkish manufacturing industry: 20052014. Energy Efficiency, 13, 649-663.

Alves, M. R. ve Moutinho, V. (2013). Decomposition analysis for energy-related $\mathrm{CO}_{2}$ emissions intensity over 1996-2009 in Portuguese industrial sectors. University of Evora. Working Paper. Evora, Portugal. Erişim adresi: https://ideas.repec.org/p/cfe/wpcefa/2013_10.html

Ang, B. W. (2005). The LMDI approach to decomposition analysis: A practical guide. Energy Policy, 33(7), 867-871.

Ang, B. W. ve Choi, K-H. (1997). Decomposition of aggregate energy and gas emission intensities for industry: A refined divisia index method. The Energy Journal, 18(3), 59-73. Erişim adresi: https://www.jstor.org/stable/41322738?seq=1\#metadata_info_tab_contents

Ang, B. W. ve Zhang, F. Q. (2000). A survey of index decomposition analysis in energy and environmental studies. Energy, 25(12), 1149-1176.

Ang, B., Zhang, F. ve Choi, K. (1998). Factorizing changes in energy and environmental indicators through decomposition. Energy, 23(6), 489-495.

Chung, W., Kam, M. S. ve Ip, C. Y. (2011). A study of residential energy use in Hong Kong by decomposition analysis, 1990-2007. Applied Energy, 88(12), 5180-5187.

Cleveland, C.J., Costanza, R., Hall, C. A. S. ve Kaufman, R. (1984). Energy and the U.S. economy: A biophysical perspective. Science, 225(4665), 890-897.

Ediger, V. S.. (2008). National energy report of Turkey: Energy situation, challenges, and policies for sustainable development. AASA Beijing Workshop on sustainable energy development in Asia 2008, November 17-18 in Beijing, China, Inter Academy Council, 77-93. Erişim adresi: http://eniva.org.tr/sysimg/dosya/2462013144114703.pdf

Ediger, V. Ş. ve Huvaz, O. (2006). Examining the sectoral energy use in Turkish Economy (1980-2000) with the help of decomposition analysis. Energy Conversion and Management, 47(6), 732-745.

Enerji ve Tabii Kaynaklar Bakanlığı (ETKB) (2020). Enerji İşleri Genel Müdürlügüu, Denge Tablolar1 (19702018).Erişim adresi: https://enerji.gov.tr/enerji-isleri-genel-mudurlugu-denge-tablolari.

European Commission (2019).Commission Staff Working Document Economic Reform Programme of Turkey (20192021).Commission Assessment. Brussels, 8549/19. Erişim adresi: https://data.consilium.europa.eu/doc/document/ST-8549-2019-INIT/en/pdf

Fan, F. ve Lei, Y. (2016). Decomposition analysis of energy-related carbon emissions from the transportation sector in Beijing. Transportation Research Part D: Transport and Environment, 42, 135-145.

Granel, F. (2003). A comparative analysis of index decomposition methods (Master Dissertation). National University of Singapore, Department of Industrial and Systems Engineering, Singapore.

Hammond, G. P. ve Norman, J. B. (2012). Decomposition analysis of energy-related carbon emissions from UK manufacturing. Energy, 41(1), 220-227.

Hastuti, S. H., Hartono, D., Putranti, T. M. ve Imansyah, M. H. (2020). The Drivers of energy-related $\mathrm{CO}_{2}$ emission changes in Indonesia: Structural decomposition analysis. Environmental Science and Pollution Research, 1-14.

Industrial Development Bank of Turkey (TSKB) (2019). Sector Overview Energy. January 2019. Erişim adresi: https://www.tskb.com.tr/i/assets/document/pdf/sector-overview-energy-2019.pdf 
Jakovac, P. (2018). Causality between energy consumption and economic growth: literature review. In INTCESS 2018-5th International Conference on Education and Social Sciences. Istanbul, Turkey, 280-289.

Jia, J., Jian, H., Xie, D., Gu, Z. ve Chen, C. (2019). Multi-scale decomposition of energy-related industrial carbon emission by an extended logarithmic mean divisia index: A case study of Jiangxi, China. Energy Efficiency, 12(8), 2161-2186.

Jobert, T. ve Karanfil, F. (2007). Sectoral energy consumption by source and economic growth in Turkey. Energy Policy, 35, 5447-5456.

Karimu, A., Brännlund, R., Lundgren, T. ve Söderholm, P. (2017). Energy intensity and convergence in Swedish industry: A combined econometric and decomposition analysis. Energy Economics, 62, 347-356.

Kazemi, H. ve Hosseinzadeh, R. (2020). Decomposition analysis of changes in energy consumption in Iran: Structural decomposition analysis. Environmental Energy and Economic Research, 4(3), 231-239.

Kim, J. ve Heo, E. (2016). Sources of structural change in energy use: A decomposition analysis for Korea. Energy Sources, Part B: Economics, Planning, and Policy, 11(4), 309-313.

Kulionis, V. ve Wood, R. (2020). Explaining decoupling in high income countries: A structural decomposition analysis of the change in energy footprint from 1970 to 2009. Energy, 116909, 1-10.

Kumbaroğlu, G. (2011). A sectoral decomposition analysis of Turkish $\mathrm{CO}_{2}$ emissions over 1990-2007. Energy, 36(5), 2419-2433.

Lise, W. (2006). Decomposition of $\mathrm{CO}_{2}$ emissions over 1980-2003 in Turkey. Energy Policy, 34(14), 1841-1852.

Moreau, V., Neves, C. A. D. O. ve Vuille, F. (2019). Is decoupling a red herring? The role of structural effects and energy policies in Europe. Energy Policy, 128, 243-252.

Moutinho, V., Moreira, A. C. ve Silva, P. M. (2015). The driving forces of change in energy-related $\mathrm{CO}_{2}$ emissions in Eastern, Western, Northern and Southern Europe: The LMDI approach to decomposition analysis. Renewable and Sustainable Energy Reviews, 50, 1485-1499.

Nie, H. ve Kemp, R. (2014). Index decomposition analysis of residential energy consumption in China: 2002-2010. Applied Energy, 121, 10-19.

OECD (2018). OECD Economic Surveys: Turkey. Erişim adresi: www.oecd.org/eco/surveys/economic-surveyturkey.htm.

Öniş, Z. (1991). Political economy of Turkey in the 1980s anatomy of unorthodox liberalism. Strong State and Economic Interest Groups, 2, 27-40.

Pokrovski, V. N. (2003). Energy in the theory of production. Energy, 28(8), 769-788.

Rada, C. ve Von Arnim, R. (2012). Structural transformation in China and India: A note on macroeconomic policies. Structural Change and Economic Dynamics, 23(3), 264-275.

Reuter, M., Patel, M. K. ve Eichhammer, W. (2019). Applying ex-post index decomposition analysis to final energy consumption for evaluating European energy efficiency policies and targets. Energy Efficiency, 12, 1329-1357.

Stern, D. I. (2010). The role of energy in economic growth. IAEE Working Paper. USAEE-IAEE WP 10-055.

Stern, D. I. (2020). (Edt.) Energy and economic growth. New York: Routledge Handbook of Energy Economics.

Stern, D.I. ve Cleveland, C.J. (2004). Energy and economic growth. Rensselaer Working Paper in Economics. No.0410. Rensselaer Polytechnic Institute, Troy, NY. Erişim adresi: http://www.rpi.edu/dept/economics/www/workingpapers/

Taka, G.N., Huong, T.T., Shah, I.H. ve Park, H.-S. (2020). Determinants of energy-based $\mathrm{CO}_{2}$ emissions in Ethiopia: A decomposition analysis from 1990 to 2017. Sustainability, 12, 4175.

Toman, M. T. ve Jemelkova, B. (2003). Energy and economic development: An assessment of the state of knowledge. Resources for the Future. Discussion Paper 03-13. Erişim adresi: https://ideas.repec.org/a/aen/journl/2003v24-04a05.html

Tunç, G. İ., Türüt-Aşı1k, S. ve Akbostanc1, E. (2009). A decomposition analysis of $\mathrm{CO}_{2}$ emissions from energy use: Turkish case. Energy Policy, 37(11), 4689-4699.

Turkey Energy Outlook (2020). Istanbul International Center for Energy and Climate (IICEC). Sabanc1 University. Erişim adresi: https://iicec.sabanciuniv.edu/teo

Türkiye İstatistik Kurumu (TÜİK) (2020). Gayrisafi Yurtiçi Hasıla, İktisadi Faaliyet Kollarına (A21) gore Zincirlenmiş Hacim, Endeks ve Değişim Oranları, 1970-2017. Erişim adresi: https://data.tuik.gov.tr/Bulten/Index?p=Yillik-Gayrisafi-Yurt-Ici-Hasila-2019-33671.

Yılmaz, A., Kelleci, S. Ü. ve Bostan, A. (2016). Türkiye ekonomisinde sektörel enerji tüketiminin ayrıştırma yöntemiyle analizi. Dokuz. Eylül Üniversitesi İktisadi ve İdari Bilimler Fakültesi Dergisi, 31(2), 1-27.

Yilmaz, M. ve Atak, M. (2010). Decomposition analysis of sectoral energy consumption in Turkey. Energy Sources, Part B: Economics, Planning, and Policy, 5(2), 224-231.

Zhang, M., Dai, S. ve Song, Y. (2015). Decomposition analysis of energy-related $\mathrm{CO}_{2}$ emissions in South Africa. Journal of Energy in Southern Africa, 26(1), 67-73.

Zhang, M., Li, H., Zhou, M. ve Mu, H. (2011). Decomposition analysis of energy consumption in Chinese transportation sector. Applied Energy, 88(6), 2279-2285.

Zhang, S., Wang, J. ve Zheng, W. (2018). Decomposition analysis of energy-related $\mathrm{CO}_{2}$ emissions and decoupling status in China's logistics industry. Sustainability, 10(5), 1340. 


\section{EXTENDED ABSTRACT}

Energy is a fundamental factor that is constantly needed to maintain current levels of economic growth and economic development. This study investigated the relationship between energy use and growth considering the fact that energy is the basic dynamics of growth. Turkey's energy consumption per capita has remained below the OECD average. However, as a developing country, Turkey expects higher energy consumption in future.

Based on this motivation, this study analyzed the main factors behind the increase in energy use by separating them by sectors and periods. The factors underlying the energy consumption in agriculture, industry, housing and services, and transportation sectors have been examined in three different periods, from 1970-1979, 1980-1999 and 2000 until today. The main reason for the separation into periods is that the country adopted a closed economy plan, an outward-oriented growth model and finally a sustainable growth approach as economic policy. The reason why energy consumption is considered separately on a sectorial basis is the expectation that energy consumption will increase as countries move from laborintensive agriculture to capital and energy-intensive industries. Therefore, this study is attempted to determine if changes in a country's growth strategy affect energy consumption sector.

In the research literature, there is often a breakdown of energy consumption by sector in Turkey. However, this study differs from other studies covering a wider period, taking into account the growth strategies of the country by periods and decomposes the services sector within itself. For this reason, it is thought that the study can play an important role in the design of sectorial-based energy policies for the future periods. This study is performed on four basic sectors, however; sectors can also be decomposed within themselves, this may be recommended for further studies.

In the study, the dynamics of the changes in energy use (output effect, structural effect, intensity effect) in agriculture, industry, housing and services, and transportation sectors between 1970 and 2018 were investigated by using the additive version of the LMDI method. LMDI decomposition analysis is a widely used approach to explain the underlying factors of energy use trends. The reason why this analysis methods are preferred, which has many advantages, is explained in detail in the text. The most important output of the empirical findings is that the most important source of the increase in the total energy use of the economy and sectors in the examined period is the increase in production (output effect). Contemporaneously with the increase in the share of energy-intensive sectors in the national income in the country, the structural effect has also increased energy consumption in the housing and services and transportation sectors, and reduced energy use in the agricultural and industrial sectors whose shares in national income tend to decrease. In addition to these effects, although the intensity effect reduce energy use, the fact that this effect remained at very limited levels besides the output effect did not prevent the net energy consumption from significant increase. However, the fact that the intensity effect has a lowering effect on energy use in all sectors except agriculture in every period can be considered as a positive development in terms of showing that energy is used efficiently. This energy intensity effect can be explained, technological developments, more efficient use of energy in the sectors and supportive policies of the government. Therefore, it is possible to say that the dynamics of changes in energy use of the sectors partially differed during the three periods when different economic policies were adopted. On the other hand, the most significant changes in both the total energy use model and the sector-based energy use model occurred during the crisis years such as 1979, 1994, 1999, 2001, 2008 and 2009. It is possible to say that these changes are related to the decrease in the output effect due to the decrease in production during the crisis periods and therefore the decrease in the energy intensity. Although it is determined that the energy use in the sectors has increased largely with the output effect over the three different periods, intervening in this situation may cause pressure on the growth. The reason for this is the output effect emerges through the increase in production. Therefore, in Turkey whose primary objective is growth, this can be an undesirable policy tool. The structural effect, on the other hand, increases the use of energy in general due to the transition to more energy-intensive sectors, the nature of the economy and the contribution of the sectors to the economy in terms of added value. Therefore, it is difficult to intervene in the structural impact in the short term, whereas transformations in the structure of the sectors can help reduce energy intensity. Energy efficiency improvements, especially in energy-intensive sectors, without any structural changes in the sectors, can contribute to preventing the increase in energy use. The findings indicate that the intensity effect has already had a lowering effect on energy use in all sectors except agriculture, but this effect is not sufficient. 
Considering that the concepts of energy use-growth and even the environment are in a strong interaction with each other, it is clear that the policies to be designed should offer an optimal solution in terms of all these variables. Therefore in Turkey, who has not yet completed the process of structural transformation and still in the early stages of development, while focusing on growth targets, pressure should be minimized on both energy resources and the environment. The findings obtained in the study show that the most effective policy tool in order to prevent the increase in energy use since the 1970s is to reduce the energy intensity. Technological innovation is essential for reducing energy intensity. In addition to these, it is thought that the initiatives aimed at creating financing for technological innovation, shifting government support from fossil fuels to renewable resources, diversifying energy supply sources and accordingly reducing the country's dependence on foreign energy can be effective policy tools.

Ek Tablo 1. Türkiye'de Toplam Birincil Enerii Kullanmmnn Toplu Ayrnstırma Analizi (btep) (1970-2018)

\begin{tabular}{|c|c|c|c|c|c|c|c|c|c|}
\hline Dönem & $\begin{array}{l}\text { Çıkt } \\
\text { Etkisi }\end{array}$ & $\begin{array}{c}\text { Yapisal } \\
\text { Etki }\end{array}$ & $\begin{array}{c}\text { Yoğunluk } \\
\text { Etkisi }\end{array}$ & $\begin{array}{c}\text { Toplam } \\
\text { Etki }\end{array}$ & Dönem & $\begin{array}{c}\text { Çıktı } \\
\text { Etkisi }\end{array}$ & $\begin{array}{c}\text { Yapisal } \\
\text { Etki }\end{array}$ & $\begin{array}{c}\text { Yoğunluk } \\
\text { Etkisi }\end{array}$ & $\begin{array}{c}\text { Toplam } \\
\text { Etki }\end{array}$ \\
\hline 1971 & 1060.578 & 127.543 & -289.578 & 898.543 & 1995 & 3098.698 & -221.911 & 1156.302 & 4033.089 \\
\hline 1972 & 1224.958 & -105.642 & 737.0417 & 1856.358 & 1996 & 3139.596 & -405.131 & 1688.404 & 4422.869 \\
\hline 1973 & 705.616 & 56.75539 & 586.384 & 1348.755 & 1997 & 3710.259 & -367.986 & -929.259 & 2413.014 \\
\hline 1974 & 1317.542 & 155.188 & -336.542 & 1136.188 & 1998 & 3441.803 & 1700.591 & -4245.8 & 896.5914 \\
\hline 1975 & 1517.514 & -60.9804 & 380.486 & 1837.02 & 1999 & -1534.1 & 394.8648 & -132.897 & -1272.14 \\
\hline 1976 & 2275.966 & -194.268 & -77.9656 & 2003.732 & 2000 & 3467.548 & -260.626 & 2384.452 & 5591.374 \\
\hline 1977 & 1120.94 & 213.9656 & 1176.06 & 2510.966 & 2001 & -2134.63 & 1442.018 & -3349.37 & -4041.98 \\
\hline 1978 & 519.6699 & 99.1044 & -616.67 & 2.104396 & 2002 & 2587.832 & -973.107 & 760.1684 & 2374.893 \\
\hline 1979 & -150.283 & 20.3043 & -1624.72 & -1754.7 & 2003 & 2518.557 & -838.689 & 2954.443 & 4634.311 \\
\hline 1980 & -299.383 & 367.9742 & 1439.383 & 1507.974 & 2004 & 6374.302 & 286.8458 & -2713.3 & 3947.846 \\
\hline 1981 & 1288.833 & -17.805 & -1199.83 & 71.19505 & 2005 & 6196.343 & 246.2141 & -4169.34 & 2273.214 \\
\hline 1982 & 1010.17 & 9.437188 & 981.8305 & 2001.437 & 2006 & 5767.021 & 764.8012 & -13.0207 & 6518.801 \\
\hline 1983 & 1287.454 & -164.001 & -626.454 & 496.999 & 2007 & 4135.244 & 296.4878 & 855.7558 & 5287.488 \\
\hline 1984 & 2032.939 & 19.57403 & -535.939 & 1516.574 & 2008 & 1475.697 & 807.3018 & -4112.7 & -1829.7 \\
\hline 1985 & 1200.321 & -138.752 & -217.321 & 844.2479 & 2009 & -6756.74 & -2982.19 & 7220.737 & -2518.19 \\
\hline 1986 & 2008.582 & -271.961 & -149.582 & 1587.039 & 2010 & 6794.66 & 368.6028 & -6154.66 & 1008.603 \\
\hline 1987 & 3026.101 & -291.065 & 1079.899 & 3814.935 & 2011 & 9975.115 & 1335.703 & -4353.12 & 6957.703 \\
\hline 1988 & 1028.3 & 205.5562 & 10.69951 & 1244.556 & 2012 & 3415.707 & -641.321 & 385.2929 & 3159.679 \\
\hline 1989 & 174.0577 & 73.36739 & 486.9423 & 734.3674 & 2013 & 8018.05 & 833.8231 & -8968.05 & -116.177 \\
\hline 1990 & 3064.328 & -591.459 & -1240.33 & 1232.541 & 2014 & 5159.391 & 700.6544 & -3489.39 & 2370.654 \\
\hline 1991 & 323.8468 & -69.5976 & 564.1532 & 818.4024 & 2015 & 5667.93 & 103.5232 & 4184.07 & 9955.523 \\
\hline 1992 & 2281.443 & -269.317 & -711.443 & 1300.683 & 2016 & 1774.967 & -1413.87 & 3359.033 & 3720.126 \\
\hline 1993 & 2939.541 & -652.678 & 634.4586 & 2921.322 & 2017 & 8656.891 & 939.9569 & -1576.89 & 8019.957 \\
\hline 1994 & -1745.48 & 889.8608 & -784.521 & -1640.14 & 2018 & -1186.69 & -2360.6 & -1455.31 & -5002.6 \\
\hline
\end{tabular}

